\title{
The Clinical Significance of the Insulin-Like Growth Factor-1 Receptor Polymorphism in Non-Small-Cell Lung Cancer with Epidermal Growth Factor Receptor Mutation
}

\author{
Tu-Chen Liu ${ }^{1,2}$, Ming-Ju Hsieh ${ }^{1,3}$, Ming-Che Liu ${ }^{4}$, Whei-Ling Chiang ${ }^{5}$, \\ Thomas Chang-Yao Tsao ${ }^{6,7, *}$ and Shun-Fa Yang ${ }^{1,8, *}$ \\ 1 Institute of Medicine, Chung Shan Medical University, Taichung 402, Taiwan; liou.dj@msa.hinet.net (T.-C.L.); \\ 170780@cch.org.tw (M.-J.H.) \\ 2 Department of Chest Medicine, Cheng-Ching General Hospital, Taichung 402, Taiwan \\ 3 Cancer Research Center, Changhua Christian Hospital, Changhua 500, Taiwan \\ 4 Department of Biochemistry and Molecular Biology, University of Massachusetts, Amherst, MA 01003, USA; \\ oldyei@gmail.com \\ 5 School of Medical Laboratory and Biotechnology, Chung Shan Medical University, Taichung 402, Taiwan; \\ wlchiang@csmu.edu.tw \\ 6 School of Medicine, Chung Shan Medical University, Taichung 402, Taiwan \\ 7 Division of Chest, Department of Internal Medicine, Chung Shan Medical University Hospital, \\ Taichung 402, Taiwan \\ 8 Department of Medical Research, Chung Shan Medical University Hospital, Taichung 402, Taiwan \\ * Correspondence: his885889@gmail.com (T.C.-Y.T.); ysf@csmu.edu.tw (S.-F.Y.); \\ Tel.: +886-4-247-395-95 (ext. 342-53) (T.C.-Y.T. \& S.-F.Y.); Fax: +886-4-232-481-83 (T.C.-Y.T. \& S.-F.Y.)
}

Academic Editor: William Chi-shing Cho

Received: 6 April 2016; Accepted: 16 May 2016; Published: 18 May 2016

\begin{abstract}
The insulin-like growth factor 1 (IGF1) signaling pathway mediates multiple cancer cell biological processes. IGF1 receptor (IGF1R) expression has been used as a reporter of the clinical significance of non-small-cell lung carcinoma (NSCLC). However, the association between IGF1R genetic variants and the clinical utility of NSCLC positive for epidermal growth factor receptor (EGFR) mutation is not clear. The current study investigated the association between the IGF1R genetic variants, the occurrence of EGFR mutations, and clinicopathological characteristics in NSCLC patients. A total of 452 participants, including 362 adenocarcinoma lung cancer and 90 squamous cell carcinoma lung cancer patients, were selected for analysis of IGF1R genetic variants (rs7166348, rs2229765, and rs8038415) using real-time polymerase chain reaction (PCR)genotyping. The results indicated that GA + AA genotypes of IGF1R rs2229765 were significantly associated with EGFR mutation in female lung adenocarcinoma patients (odds ratio $(\mathrm{OR})=0.39,95 \%$ confidence interval $(C I)=0.17-0.87)$. Moreover, The GA + AA genotype IGF1R rs2229765 was significantly associated with EGFR L858R mutation ( $p=0.02$ ) but not with the exon 19 in-frame deletion. Furthermore, among patients without EGFR mutation, those who have at least one polymorphic A allele of IGF1R rs7166348 have an increased incidence of lymph node metastasis when compared with those patients homozygous for GG (OR, 2.75; 95\% CI, 1.20-2.31). Our results showed that IGF1R genetic variants are related to EGFR mutation in female lung adenocarcinoma patients and may be a predictive factor for tumor lymph node metastasis in Taiwanese patients with NSCLC.
\end{abstract}

Keywords: non-small-cell lung carcinoma; insulin-like growth factor 1 receptor; epidermal growth factor receptor; genetic variants 


\section{Introduction}

Lung cancer is a common type of cancer worldwide [1]. Two primary types of lung cancer are small cell lung carcinoma (SCLC) and non-small-cell lung carcinoma (NSCLC). Among lung cancers, NSCLC accounts for approximately $80 \%$ [2]. Common types of NSCLC include adenocarcinoma, squamous cell carcinoma, and large cell carcinoma.

The epidermal growth factor receptor (EGFR) is a transmembrane growth factor receptor with tyrosine kinase (TK) activity that plays a critical role for transmitting growth factor signaling from the extracellular region into the cell [3]. In the intracellular region, the following signaling transduction is regulated mainly through the PI3K-AKT-mTOR pathway, the RAS-RAF-MEK-ERK pathway and the signal transducer and activator of transcription (STAT) pathway [4]. The EGFR singling system is important for cell proliferation, differentiation, and anti-apoptosis [4,5]. It has been reported that mutation in the TK domain of EGFR gene is associated with NSCLC [6-8]. The most common mutations in the TK domain of EGFR are the in-frame deletion mutation in exon 19 and the substitution mutation (L858R) in exon 21. Mutation in the TK domain of EGFR causes the conformational change in protein structure. This results in constitutive TK activity and its downstream signaling pathway $[9,10]$. The EGFR is considered a therapeutic target for treatment in NSCLC. It has been reported that gefitinib and erlotinib are EGFR tyrosine kinase inhibitors (TKIs) for in-frame deletion in exon 19 and the substitution mutation (L858R) in exon 21 [6-8].

The insulin-like growth factor 1 (IGF1) signaling pathway mediates multiple cell biological processes including proliferation, differentiation, and metabolism [11]. The IGF1 system is composed of ligands, receptors, and a family of IGF binding proteins (IFGBPs). While IFG1 binds to insulin-like growth factor 1 receptor (IGF1R) on the cell membrane, the receptor-type tyrosine kinase IGF1R will be activated by autophosphorylation and switch on the downstream intracellular signaling transduction pathways, including the PI3K-PDK1-AKT pathway and the RAS-RAF-MEK-ERK pathway [12,13]. These pathways are vital for cell proliferation, differentiation, and anti-apoptosis [11,14]. Numerous studies have demonstrated that dysfunction of the IGF1 signaling pathway results in various diseases, including cancer, metabolic disease, as well as neurodegenerative diseases [15-17]. In addition, IGF1 system dysregulation has been reported in cancers such as NSCLC and in other tumors [18]. Recently, the clinical significance of IFG1R expression in human NSCLC has been reported [19]. The results showed that high membranous IGF1R expression was predictive of poor progression-free survival (PFS) in adenocarcinoma, but had better PFS in squamous cell carcinoma [19]. Moreover, Reinmuth et al. [20] also characterized the IGF1R mutations, single nucleotide polymorphisms (SNPs), and protein expression in resected NSCLC and found that patients with adenocarcinomas and homozygous for the rs 8038415 T-allele had significantly better survival, but found no different in disease free survival. These findings indicate that IGF1R could be a potential therapeutic target and will guide further investigation.

Contributions of the IGF1R expression to the formation of NSCLC have been well established [18]. However, the correlation between IGF1R gene polymorphisms and the hotspot mutations of EGFR (in-frame deletion mutation in exon 19 and L858R mutation) of NSCLC have not been clarified. In the present study, the selection of two common polymorphisms (rs7166348 and rs8038415) from the IGF1R gene is based on their wide associations with the development of cancer [20,21]. Moreover, synonymous with the SNP, rs2229765 (E598E in exon 16) was selected in this study since it was found to be associated with levels of free IGF-1 [22]. Thus, in this study we aimed to explore the association between the genetic SNPs of IGF1R (rs7166348, rs2229765, and rs8038415) and the TK-domain mutations of EGFR in NSCLC. These results may provide a clue to understanding the potential consequences of lung cancer.

\section{Results}

A total of 452 patients were enrolled in this study. The demographics and clinical characteristics of patients were shown in Table 1 . The average age of patients was 66 years. The gender distribution in 
patients was 251 male (55.5\%) and 201 female (44.5\%) with a sex ratio of about 1 . Across all patients, the percentages of adenocarcinoma and squamous cell carcinoma were $81.1 \%(362 / 452)$ and $19.9 \%(90 / 452)$ respectively. Moreover, female patients possessed higher frequency (male vs. female $=47.2 \% v$ s. $52.8 \%$ ) in the adenocarcinoma. In contrast, male patients showed a higher frequency of squamous cell carcinoma (male vs. female $=89.9 \%$ vs. $11.1 \%$ ). As regards cigarette smoking, it was shown that 58\% (262/452) had never smoked (never-smokers) and 42\% (190/452) were current or former smokers (ever-smokers). Furthermore, never-smoking patients had higher frequency (never-smokers vs. ever-smokers $=66.9 \%$ vs. $33.1 \%$ ) in the adenocarcinoma and lower frequency (never-smokers $v s$. ever-smokers $=22.2 \%$ vs. $77.8 \%)$ in the squamous cell carcinoma $(p<0.001)$.

Table 1. Demographics and clinical characteristics of 452 patients with lung adenocarcinoma and lung squamous cell carcinoma.

\begin{tabular}{|c|c|c|c|c|}
\hline Variable & $\begin{array}{c}\text { All Cases } \\
(N=452) n(\%)\end{array}$ & $\begin{array}{l}\text { Adenocarcinoma } \\
(N=362) n(\%)\end{array}$ & $\begin{array}{l}\text { Squamous Cell } \\
\text { Carcinoma }(N=90) n(\%)\end{array}$ & $p$-Value \\
\hline \multicolumn{5}{|l|}{ Age } \\
\hline$<30$ & $3(0.7 \%)$ & $3(0.8 \%)$ & $0(0 \%)$ & \multirow{6}{*}{$p=0.732$} \\
\hline $30-39$ & $9(2.0 \%)$ & $8(2.2 \%)$ & $1(1.1 \%)$ & \\
\hline $40-49$ & $40(8.8 \%)$ & $33(9.1 \%)$ & $7(7.8 \%)$ & \\
\hline $50-59$ & $96(21.2 \%)$ & $80(22.1 \%)$ & $16(17.8 \%)$ & \\
\hline $60-69$ & $99(21.9 \%)$ & $76(21.0 \%)$ & $23(25.6 \%)$ & \\
\hline$\geqslant 70$ & $205(45.4 \%)$ & $162(44.8 \%)$ & $43(47.8 \%)$ & \\
\hline Mean \pm SD & $66.27 \pm 13.85$ & $65.82 \pm 13.95$ & $68.06 \pm 13.37$ & $p=0.171$ \\
\hline \multicolumn{5}{|l|}{ Gender } \\
\hline Male & $251(55.5 \%)$ & $171(47.2 \%)$ & $80(88.9 \%)$ & \multirow[t]{2}{*}{$p<0.001$} \\
\hline Female & $201(44.5 \%)$ & $191(52.8 \%)$ & $10(11.1 \%)$ & \\
\hline \multicolumn{5}{|c|}{ Cigarette Smoking Status } \\
\hline Never-smoker & $262(58.0 \%)$ & $242(66.9 \%)$ & $20(22.2 \%)$ & \multirow[t]{2}{*}{$p<0.001$} \\
\hline Ever-smoker & $190(42.0 \%)$ & $120(33.1 \%)$ & $70(77.8 \%)$ & \\
\hline pack-years & $39.22 \pm 29.62$ & $33.29 \pm 28.80$ & $52.95 \pm 26.98$ & $p<0.001$ \\
\hline \multicolumn{5}{|l|}{ Disease Stage } \\
\hline IA & $45(10.0 \%)$ & $41(11.3 \%)$ & $4(4.4 \%)$ & \multirow[t]{7}{*}{$p<0.001$} \\
\hline IB & $57(12.6 \%)$ & $52(14.4 \%)$ & $5(5.6 \%)$ & \\
\hline IIA & $27(6.0 \%)$ & $21(5.8 \%)$ & $6(6.7 \%)$ & \\
\hline IIB & $10(2.2 \%)$ & $7(1.9 \%)$ & $3(3.3 \%)$ & \\
\hline IIIA & $40(8.8 \%)$ & $29(8.0 \%)$ & $11(12.2 \%)$ & \\
\hline IIIB & $67(14.8 \%)$ & $39(10.8 \%)$ & $28(31.1 \%)$ & \\
\hline IV & $206(45.6 \%)$ & $173(47.8 \%)$ & $33(36.7 \%)$ & \\
\hline \multicolumn{5}{|c|}{ Cell Differentiation } \\
\hline Good & $42(9.3 \%)$ & $39(10.8 \%)$ & $3(3.3 \%)$ & \multirow[t]{3}{*}{$p<0.001$} \\
\hline Moderate & $326(72.1 \%)$ & $280(77.3 \%)$ & $46(51.1 \%)$ & \\
\hline Poor & $84(18.6 \%)$ & $43(11.9 \%)$ & $41(45.6 \%)$ & \\
\hline
\end{tabular}

The distribution frequency of rs7166348, rs2229765, and rs8038415 of IGF1R genotypes in the lung adenocarcinoma and squamous cell carcinoma are shown in Table 2 . The alleles with the highest distribution frequency for rs7166348, rs2229765, and rs8038415 of IGF1R in recruited patients with NSCLC were heterozygous G/A, homozygous G/G, and heterozygous $T / C$, respectively. After adjusting for variance, there was no significant difference between the lung adenocarcinoma and squamous cell carcinoma with polymorphisms of the IGF1R gene in rs7166348, rs2229765, and rs8038415 when compared with wild-type individuals. 
Table 2. Distribution frequency of insulin-like growth factor 1 receptor (IGF1R) genotypes in 362 lung adenocarcinoma and 90 lung squamous cell carcinoma.

\begin{tabular}{ccccc}
\hline Variable & $\begin{array}{c}\text { Adenocarcinoma } \\
(\mathbf{N = 3 6 2 )} \mathbf{( \% )}\end{array}$ & $\begin{array}{c}\text { Squamous Cell } \\
\text { Carcinoma }(\mathbf{N}=\mathbf{9 0}) \mathbf{( \% )}\end{array}$ & $\begin{array}{c}\text { Odds Ratio (95\% } \\
\text { Confidence Interval) }\end{array}$ & $\begin{array}{c}\text { Adjusted Odds } \\
\text { Ratio (95\% CI) }\end{array}$ \\
\hline IGF1R rs7166348 & & & & \\
GG & $117(32.3 \%)$ & $34(37.8 \%)$ & 1.00 & 1.00 \\
GA & $189(52.2 \%)$ & $44(48.9 \%)$ & $0.80(0.48-1.33)$ & $0.67(0.39-1.18)$ \\
AA & $56(15.5 \%)$ & $12(13.3 \%)$ & $0.74(0.36-1.53)$ & $0.69(0.31-1.54)$ \\
GA + AA & $245(67.7 \%)$ & $56(62.2 \%)$ & $0.79(0.49-1.27)$ & $0.68(0.40-1.15)$ \\
\hline IGF1R rs2229765 & & & & 1.00 \\
GG & $168(46.4 \%)$ & $43(47.8 \%)$ & $0.86(0.52-1.41)$ & $0.90(0.52-1.55)$ \\
GA & $155(42.8 \%)$ & $34(37.8 \%)$ & $1.30(0.64-2.65)$ & $2.08(0.92-4.72)$ \\
AA & $39(10.8 \%)$ & $13(14.4 \%)$ & $0.95(0.60-1.50)$ & $1.08(0.65-1.79)$ \\
GA + AA & $194(53.6 \%)$ & $47(52.2 \%)$ & & 1.00 \\
\hline IGF1R rs8038415 & & & $0.66(0.38-1.16)$ & $0.61(0.33-1.13)$ \\
TT & $90(24.9 \%)$ & $27(30.0 \%)$ & $1.01(0.55-1.86)$ & $1.02(0.52-2.03)$ \\
TC & $186(51.4 \%)$ & $37(41.1 \%)$ & $0.77(0.46-1.29)$ & $0.73(0.42-1.29)$ \\
CC & $86(23.7 \%)$ & $26(28.9 \%)$ & & \\
TC + CC & $272(75.1 \%)$ & $63(70.0 \%)$ & & \\
\hline
\end{tabular}

We further investigated the associations between EGFR mutations and patient characteristics. As shown in Table 3, both substitution mutation (L858R) and exon 19 in-frame deletion mutations had higher percentages in female patients (male vs. female $=22.8 \%$ vs. $77.2 \%$ and $46.9 \%$ vs. $53.1 \%$, respectively) and in never-smoker patients (never-smokers vs. ever-smokers $=88.6 \%$ vs. $11.4 \%$ and $69.1 \%$ vs. $30.9 \%$, respectively). The distributions were shown to be significantly different between the control (wild-type) and EGFR mutations for gender $(p<0.05)$ and cigarette smoking status $(p<0.05)$. These results indicate that EGFR mutations are associated with gender and cigarette smoking status.

Table 3. Demographics and clinical characteristics of 279 patients in lung adenocarcinoma with epidermal growth factor receptor (EGFR) mutation status.

\begin{tabular}{|c|c|c|c|c|}
\hline Variable & $\begin{array}{c}\text { Wild Type } \\
(N=110) n(\%)\end{array}$ & $\begin{array}{c}\text { L858R }(N=79) \\
n(\%)\end{array}$ & $\begin{array}{l}\text { In-Frame Deletion } \\
\quad(N=81) n(\%)\end{array}$ & $\begin{array}{c}\text { Others }(N=9) \\
n(\%)\end{array}$ \\
\hline \multicolumn{5}{|l|}{ Age } \\
\hline$<30$ & $1(0.9 \%)$ & $0(0 \%)$ & $1(1.2 \%)$ & $0(0 \%)$ \\
\hline $30-39$ & $3(2.7 \%)$ & $0(0 \%)$ & $2(2.5 \%)$ & $0(0 \%)$ \\
\hline $40-49$ & $11(9.9 \%)$ & $6(7.6 \%)$ & $10(12.3 \%)$ & $0(0 \%)$ \\
\hline $50-59$ & $21(18.9 \%)$ & $16(20.3 \%)$ & $27(33.3 \%)$ & $1(11.1 \%)$ \\
\hline $60-69$ & $26(23.4 \%)$ & $16(20.3 \%)$ & $14(17.3 \%)$ & $1(11.1 \%)$ \\
\hline$\geqslant 70$ & $49(44.1 \%)$ & $41(51.9 \%)$ & $27(33.3 \%)$ & $7(77.8 \%)$ \\
\hline Mean \pm SD & $65.36 \pm 13.42$ & $68.18 \pm 12.56$ & $62.31 \pm 14.01^{\mathrm{b}}$ & $75.56 \pm 9.04$ \\
\hline \multicolumn{5}{|l|}{ Gender } \\
\hline Male & $67(60.4 \%)$ & $18(22.8 \%)^{a}$ & $38(46.9 \%)^{b}$ & $4(44.4 \%)$ \\
\hline Female & $44(39.6 \%)$ & $61(77.2 \%)$ & $43(53.1 \%)$ & $5(55.6 \%)$ \\
\hline \multicolumn{5}{|c|}{ Cigarette Smoking Status } \\
\hline Never-smoker & $50(45.0 \%)$ & $70(88.6 \%)^{a}$ & $56(69.1 \%)^{a}$ & $5(55.6 \%)$ \\
\hline Ever-smoker & $61(55.0 \%)$ & $9(11.4 \%)$ & $25(30.9 \%)$ & $4(44.4 \%)$ \\
\hline PPK & $46.32 \pm 28.21$ & $12.76 \pm 20.81^{a}$ & $21.15 \pm 23.15^{\mathrm{a}}$ & $46.00 \pm 28.15$ \\
\hline
\end{tabular}

\footnotetext{
a Significant difference when compared with wild-type group, $p$-value $<0.05$; ${ }^{\mathrm{b}}$ Significant difference when
} compared with L858R group, $p$-value $<0.05$. 
Table 3. Cont.

\begin{tabular}{|c|c|c|c|c|}
\hline Variable & $\begin{array}{c}\text { Wild Type } \\
(N=110) n(\%)\end{array}$ & $\begin{array}{c}\text { L858R }(N=79) \\
n(\%)\end{array}$ & $\begin{array}{l}\text { In-Frame Deletion } \\
\quad(N=81) n(\%)\end{array}$ & $\begin{array}{c}\text { Others }(N=9) \\
n(\%)\end{array}$ \\
\hline \multicolumn{5}{|c|}{ Disease Stage } \\
\hline IA & $11(9.9 \%)$ & $6(7.6 \%)$ & $11(13.6 \%)$ & $0(0 \%)$ \\
\hline IB & $9(8.1 \%)$ & $13(16.5 \%)$ & $9(11.1 \%)$ & $1(11.1 \%)$ \\
\hline IIA & $5(4.5 \%)$ & $4(5.1 \%)$ & $3(3.7 \%)$ & $0(0 \%)$ \\
\hline IIB & $1(0.9 \%)$ & $0(0 \%)$ & $0(0 \%)$ & $0(0 \%)$ \\
\hline IIIA & $10(9.0 \%)$ & $7(8.9 \%)$ & $4(4.9 \%)$ & $0(0 \%)$ \\
\hline IIIB & $17(15.3 \%)$ & $10(12.7 \%)$ & $7(8.6 \%)$ & $2(22.2 \%)$ \\
\hline IV & $58(52.3 \%)$ & $39(49.4 \%)$ & $47(58.0 \%)$ & $6(66.7 \%)$ \\
\hline \multicolumn{5}{|c|}{ Cell Differentiation } \\
\hline Good & $8(7.2 \%)$ & $11(13.9 \%)^{a}$ & $8(9.9 \%)^{a}$ & $2(22.2 \%)$ \\
\hline Moderate & $80(72.1 \%)$ & $63(79.7 \%)$ & $68(84.0 \%)$ & $7(77.8 \%)$ \\
\hline Poor & $23(20.7 \%)$ & $5(6.3 \%)$ & $5(6.1 \%)$ & $0(0 \%)$ \\
\hline
\end{tabular}

a Significant difference when compared with wild-type group, $p$-value $<0.05 ;{ }^{b}$ Significant difference when compared with L858R group, $p$-value $<0.05$.

To clarify the association between the polymorphism of IFG1R gene and EGFR mutation in different gender groups, the distribution frequency of IGF1R gene (rs7166348, rs2229765, and rs8038415) genotypes of wild-type and EGFR mutation type in lung adenocarcinoma patients was estimated. As shown in Table 4, GA and GA + AA genotypes of IGF1R rs2229765 had significant association with EGFR mutation in female lung adenocarcinoma patients $(\mathrm{OR}=0.35,95 \% \mathrm{CI}=0.15-0.82$ and $\mathrm{OR}=0.39,95 \% \mathrm{CI}=0.17-0.87$, respectively). Additionally from Table 4 , the polymorphism of IGF1R rs2229765 was associated with EGFR mutation only in female lung adenocarcinoma patients. Therefore, further analyses were focused on the association between the polymorphism of IFG1R gene and EGFR hotspot mutations in female lung adenocarcinoma patients. Table 5 shows that the GA and GA + AA genotypes of IGF1R rs2229765 demonstrated significant association with L858R mutation in female lung adenocarcinoma patients $(\mathrm{OR}=0.35,95 \% \mathrm{CI}=0.14-0.88$ and $\mathrm{OR}=0.34,95 \% \mathrm{CI}=0.14-0.84$, respectively). These results indicate that the polymorphisms of IGF1R rs2229765 gene are associated with L858R mutation in female adenocarcinoma patients.

Table 4. Distribution frequency of IGF1R genotypes, the 111 EGFR wild type, and the 169 EGFR mutation type in lung adenocarcinoma patients.

\begin{tabular}{cccc}
\hline \multirow{2}{*}{ Variable } & \multicolumn{3}{c}{ All Cases $(\mathbf{N}=\mathbf{2 8 0})$} \\
\cline { 2 - 4 } & Wild Type $(\boldsymbol{N}=\mathbf{1 1 1}) \mathbf{( \% )}$ & Mutation Type $(\boldsymbol{N}=\mathbf{1 6 9 )} \mathbf{( \% )}$ & AOR (95\% CI) \\
\hline IGF1R rs7166348 & $36(32.4 \%)$ & $50(29.6 \%)$ & 1.00 \\
GG & $59(53.2 \%)$ & $89(52.7 \%)$ & $1.30(0.72-2.32)$ \\
GA & $16(14.4 \%)$ & $30(17.7 \%)$ & $1.49(0.67-3.28)$ \\
AA & $75(67.6 \%)$ & $119(70.4 \%)$ & $1.34(0.77-2.34)$ \\
GA + AA & & & \\
\hline IGF1R rs2229765 & $48(43.2 \%)$ & $81(47.9 \%)$ & 1.00 \\
GG & $50(45.0 \%)$ & $69(40.8 \%)$ & $0.75(0.43-1.29)$ \\
GA & $13(11.8 \%)$ & $19(11.3 \%)$ & $0.69(0.29-1.65)$ \\
AA & $63(56.8 \%)$ & $88(52.1 \%)$ & $0.73(0.44-1.24)$ \\
GA + AA & & & 1.00 \\
\hline IGF1R rs8038415 & $29(26.1 \%)$ & $42(24.9 \%)$ & $1.23(0.66-2.30)$ \\
TT & $51(45.9 \%)$ & $38(52.1 \%)$ & $1.11(0.54-2.27)$ \\
TC & $31(27.9 \%)$ & $127(75.1 \%)$ & $1.19(0.66-2.13)$ \\
CC & $80(73.9 \%)$ & &
\end{tabular}


Table 4. Cont.

\begin{tabular}{|c|c|c|c|}
\hline \multirow{2}{*}{ Variable } & \multicolumn{3}{|c|}{ All Cases $(N=280)$} \\
\hline & Wild Type $(N=111)(\%)$ & Mutation Type $(N=169)(\%)$ & AOR $(95 \% \mathrm{CI})$ \\
\hline \multicolumn{4}{|c|}{ Male $(N=127)$} \\
\hline \multicolumn{4}{|l|}{ IGF1R rs7166348 } \\
\hline GG & $21(31.3 \%)$ & $14(23.3 \%)$ & 1.00 \\
\hline GA & $38(56.7 \%)$ & $34(56.7 \%)$ & $2.08(0.63-6.95)$ \\
\hline AA & $8(12.0 \%)$ & $12(20.0 \%)$ & $4.70(0.90-24.52)$ \\
\hline $\mathrm{GA}+\mathrm{AA}$ & $46(68.7 \%)$ & $46(76.7 \%)$ & $2.48(0.99-6.20)$ \\
\hline \multicolumn{4}{|l|}{ IGF1R rs2229765 } \\
\hline GG & $35(43.2 \%)$ & $28(46.7 \%)$ & 1.00 \\
\hline GA & $26(45.0 \%)$ & $26(43.3 \%)$ & $1.27(0.57-2.82)$ \\
\hline AA & $6(11.8 \%)$ & $6(10.0 \%)$ & $1.02(0.25-4.17)$ \\
\hline $\mathrm{GA}+\mathrm{AA}$ & $32(47.8 \%)$ & $32(53.3 \%)$ & $1.22(0.57-2.59)$ \\
\hline \multicolumn{4}{|l|}{ IGF1R rs8038415 } \\
\hline TT & $16(23.9 \%)$ & $16(26.7 \%)$ & 1.00 \\
\hline $\mathrm{TC}$ & $34(50.7 \%)$ & $27(45.0 \%)$ & $0.93(0.36-2.40)$ \\
\hline $\mathrm{CC}$ & $17(25.4 \%)$ & $17(28.3 \%)$ & $1.24(0.44-3.56)$ \\
\hline $\mathrm{TC}+\mathrm{CC}$ & $51(76.1 \%)$ & $44(73.3 \%)$ & $1.04(0.43-2.51)$ \\
\hline \multicolumn{4}{|c|}{ Female $(N=153)$} \\
\hline IGF1R rs7166348 & $15(34.1 \%)$ & $36(33.0 \%)$ & 1.00 \\
\hline GG & $21(47.7 \%)$ & $55(50.5 \%)$ & $1.21(0.53-2.77)$ \\
\hline GA & $8(18.2 \%)$ & $18(16.5 \%)$ & $1.14(0.37-3.49)$ \\
\hline AA & $29(65.9 \%)$ & $73(67.0 \%)$ & $1.19(0.54-2.60)$ \\
\hline \multicolumn{4}{|l|}{$\mathrm{GA}+\mathrm{AA}$} \\
\hline IGF1R rs2229765 & $13(29.5 \%)$ & $53(48.6 \%)$ & 1.00 \\
\hline GG & $24(54.5 \%)$ & $43(39.4 \%)$ & $0.35(0.15-0.82)$ \\
\hline GA & $7(16.0 \%)$ & $13(12.0 \%)$ & $0.54(0.16-2.85)$ \\
\hline $\mathrm{AA}$ & $31(70.5 \%)$ & $56(51.4 \%)$ & $0.39(0.17-0.87)$ \\
\hline \multicolumn{4}{|l|}{$\mathrm{GA}+\mathrm{AA}$} \\
\hline \multicolumn{4}{|l|}{ IGF1R rs8038415 } \\
\hline TT & $13(29.5 \%)$ & $26(23.9 \%)$ & 1.00 \\
\hline $\mathrm{TC}$ & $17(38.6 \%)$ & $61(55.9 \%)$ & $1.61(0.66-3.97)$ \\
\hline $\mathrm{CC}$ & $14(31.9 \%)$ & $22(20.2 \%)$ & $0.84(0.30-2.35)$ \\
\hline $\mathrm{TC}+\mathrm{CC}$ & $31(70.5 \%)$ & $83(76.1 \%)$ & $1.30(0.56-2.98)$ \\
\hline
\end{tabular}

Table 5. The associations between the polymorphisms of IGF1R and the EGFR hotspot mutations in female lung adenocarcinoma patients.

\begin{tabular}{cccccc}
\hline \multirow{2}{*}{ Variable } & Wild Type & \multicolumn{2}{c}{ L858R } & \multicolumn{2}{c}{ Exon 19 in-Frame Deletion } \\
\cline { 2 - 6 } & $\mathbf{( N = 4 4 )} \boldsymbol{n} \mathbf{( \% )}$ & $\mathbf{( N = 6 1 ) ( \% )}$ & AOR (95\% CI) & $\mathbf{( N = 4 3 ) ~ ( \% )}$ & AOR (95\% CI) \\
\hline IGF1R rs7166348 & & & & \\
GG & $15(34.1 \%)$ & $22(34.1 \%)$ & 1.00 & $12(27.9 \%)$ & 1.00 \\
GA & $21(47.7 \%)$ & $29(47.7 \%)$ & $1.17(0.45-3.01) p=0.746$ & $23(53.5 \%)$ & $1.47(0.53-4.04) p=0.458$ \\
AA & $8(18.2 \%)$ & $10(18.2 \%)$ & $1.12(0.31-4.11) p=0.864$ & $8(18.6 \%)$ & $1.38(0.36-5.38) p=0.640$ \\
GA + AA & $29(65.9 \%)$ & $39(63.9 \%)$ & $1.16(0.47-2.86) p=0.751$ & $31(72.1 \%)$ & $1.45(0.55-3.77) p=0.452$ \\
\hline IGF1R rs2229765 & & & & \\
GG & $13(29.5 \%)$ & $34(55.7 \%)$ & 1.00 & $15(34.9 \%)$ & 1.00 \\
GA & $24(54.5 \%)$ & $22(36.1 \%)$ & $0.35(0.14-0.88) p=0.026$ & $21(48.8 \%)$ & $0.53(0.19-1.49) p=0.227$ \\
AA & $7(16.0 \%)$ & $5(8.2 \%)$ & $0.35(0.08-1.52) p=0.160$ & $7(16.3 \%)$ & $0.85(0.20-3.66) p=0.829$ \\
GA + AA & $31(70.5 \%)$ & $27(44.3 \%)$ & $0.34(0.14-0.84) p=0.020$ & $28(65.1 \%)$ & $0.58(0.22-1.58) p=0.290$ \\
\hline IGF1R rs8038415 & & & & \\
TT & $13(29.5 \%)$ & $15(24.6 \%)$ & 1.00 & $10(23.3 \%)$ & 1.00 \\
TC & $17(38.6 \%)$ & $33(54.1 \%)$ & $1.77(0.65-4.85) p=0.268$ & $25(58.1 \%)$ & $1.47(0.50-4.35) p=0.484$ \\
CC & $14(31.9 \%)$ & $13(21.3 \%)$ & $1.00(0.32-3.16) p=0.999$ & $8(18.6 \%)$ & $0.68(0.18-2.53) p=0.560$ \\
TC + CC & $31(70.5 \%)$ & $46(75.4 \%)$ & $1.45(0.57-3.66) p=0.434$ & $33(76.7 \%)$ & $1.16(0.42-3.21) p=0.780$ \\
\hline
\end{tabular}


The clinical stage of cancer is a standard way for doctors to understand the time of tumor formation. In this study, the clinicopathological characteristics of lung cancer have been divided into four stages (N0, N1, N2, and N3), dependent on numbers of lymph nodes to which the cancer has spread. We further reveal the association between polymorphisms of IGF1R gene and different clinical $\mathrm{N}$ stage of lung cancer in different types of patients. As shown in Table 6, GA + AA genotype of IGF1R rs7166348 was shown to be significantly associated with the clinical $\mathrm{N}$ stage in lung adenocarcinoma $(\mathrm{OR}=1.66,95 \% \mathrm{CI}=1.07-2.95 ; p=0.024)$. Moreover, similar results were found in the wild-type lung adenocarcinoma patients $(\mathrm{OR}=2.75,95 \% \mathrm{CI}=1.20-6.31 ; p=0.015)$. These findings indicate that the polymorphisms of IGF1R rs7166348 may be associated with the clinical N stage of lung cancer.

Table 6. Associations between polymorphic genotypes of IGF1R rs7166348 and clinicopathologic characteristics of lung cancer.

\begin{tabular}{|c|c|c|c|c|}
\hline \multirow{2}{*}{ Variable Genotypefrequencies } & \multicolumn{4}{|c|}{ Clinical Stage } \\
\hline & $\mathrm{N} 0+\mathrm{N} 1$ & $\mathrm{~N} 2+\mathrm{N} 3$ & OR $(95 \% \mathrm{CI})$ & $p$-Value \\
\hline All Cases $(N=452)$ & $(N=151)$ & $(N=185)$ & & \\
\hline $\begin{array}{c}I G F 1 R \\
\text { rs7166348 GG }\end{array}$ & $68(45.0 \%)$ & $116(38.5 \%)$ & 1.00 & \\
\hline $\mathrm{GA}+\mathrm{AA}$ & $83(55.0 \%)$ & $185(61.5 \%)$ & $1.31(0.88-1.94)$ & $p=0.185$ \\
\hline adenocarcinoma $(N=362)$ & $(N=117)$ & $(N=245)$ & & \\
\hline $\begin{array}{c}I G F 1 R \\
\text { rs7166348 GG }\end{array}$ & $62(53.0 \%)$ & $99(40.4 \%)$ & 1.00 & \\
\hline $\mathrm{GA}+\mathrm{AA}$ & $55(47.0 \%)$ & $146(59.6 \%)$ & $1.66(1.07-2.59)$ & $p=0.024$ \\
\hline Squamous Cell Carcinoma $(N=90)$ & $(N=34)$ & $(N=56)$ & & \\
\hline $\begin{array}{c}I G F 1 R \\
\text { rs7166348 GG }\end{array}$ & $6(17.6 \%)$ & $17(30.4 \%)$ & 1.00 & \\
\hline $\mathrm{GA}+\mathrm{AA}$ & $28(82.4 \%)$ & $39(69.6 \%)$ & $0.49(0.17-1.40)$ & $p=0.180$ \\
\hline Wild Type $(N=111)$ & $(N=36)$ & $(N=75)$ & & \\
\hline $\begin{array}{c}I G F 1 R \\
\text { rs7166348 GG }\end{array}$ & $18(50.0 \%)$ & $20(26.7 \%)$ & 1.00 & \\
\hline $\mathrm{GA}+\mathrm{AA}$ & $18(50.0 \%)$ & $55(73.3 \%)$ & $2.75(1.20-6.31)$ & $p=0.015$ \\
\hline L858R $(N=79)$ & $(N=28)$ & $(N=51)$ & & \\
\hline $\begin{array}{c}I G F 1 R \\
\text { rs7166348 GG }\end{array}$ & $13(46.4 \%)$ & $21(41.2 \%)$ & 1.00 & \\
\hline $\mathrm{GA}+\mathrm{AA}$ & $15(53.6 \%)$ & $30(58.8 \%)$ & $1.24(0.49-3.13)$ & $p=0.652$ \\
\hline In-Frame Deletion $(N=81)$ & $(N=20)$ & $(N=61)$ & & \\
\hline $\begin{array}{c}I G F 1 R \\
\text { rs7166348 GG }\end{array}$ & $5(25.0 \%)$ & $21(34.4 \%)$ & 1.00 & \\
\hline $\mathrm{GA}+\mathrm{AA}$ & $15(75.0 \%)$ & $40(65.6 \%)$ & $0.64(0.20-1.99)$ & $p=0.433$ \\
\hline
\end{tabular}

\section{Discussion}

Mutations in the TK domain of the EGFR gene were associated with NSCLC [6-8]. Previous studies have reported that EGFR mutations had higher frequency in adenocarcinoma than other types of NSCLCs, in never-smoker as opposed to ever-smokers, and in females rather than males [22-24]. Indeed, as shown in Table 3, both substitution mutation (L858R) and in-frame deletion mutation were shown to have a higher frequency in female patients (male $v$ s. female $=22.8 \%$ vs. $77.2 \%$ and $46.9 \%$ vs. $53.1 \%$, respectively) and in never-smoker patients (never-smokers vs. ever-smokers $=88.6 \%$ vs. $11.4 \%$ and $69.1 \%$ vs. $30.9 \%$, respectively). These results were consistent with previous studies indicating that the mutation of EGFR was associated with adenocarcinoma, smoking status, and gender [22-24].

The IGF1 signaling pathway mediates multiple cell biological processes including proliferation, differentiation, and metabolism [11]. In previous studies, polymorphism of the IGF1R rs2229765 
gene was associated with levels of free IGF1 and human longevity $[25,26]$. In addition, it has been reported that IGF1R rs7166348 gene and IGF1 levels are associated with colorectal neoplasia [22]. However, fewer studies were reported for association between IGF1R gene polymorphisms and lung cancer. Reinmuth et al. [20] have reported the clinical significance of IGF1R single nucleotide polymorphisms (SNPs) in resected NSCLC. The results showed that the TT genotype of IGF1R 7166348 gave a significantly better survival rate in adenocarcinoma lung cancer. In this study, we have reported the relationship between the polymorphism of the IGFIR gene and EGFR mutation in NSCLC. In our studies, three SNPs (rs7166348, rs2229765, and rs8038415) of IGF1R were used. The results shown in Tables 4 and 5 indicated that GA and GA + AA genotypes of the IGF1R rs2229765 gene are associated with the L858R mutation of the EGFR in the female lung adenocarcinoma patients. However, the mechanism by which this SNP modulates the roles of female lung adenocarcinoma patients should be further investigated.

Further, we separated the clinical N stages of patients into two subgroup according the lymph nodes metastasis status. As shown in Table 6, GA + AA genotype of IGF1R rs7166348 shows significant association with the clinical stage in lung adenocarcinoma $(\mathrm{OR}=1.66,95 \% \mathrm{CI}=1.07-2.59)$. Furthermore, GA + AA genotype of IGF1R rs7166348 was also shown to be significantly associated with clinical $\mathrm{N}$ stage in wild-type lung adenocarcinoma patients $(\mathrm{OR}=2.75,95 \% \mathrm{CI}=1.20-6.31)$. These findings implied a relationship linking the polymorphism of the IGFIR gene to the clinical $\mathrm{N}$ stage of lung cancer. In addition, previous reports have indicated that rs7166348 in IGF1R was more strongly associated with IGF1 levels in colorectal neoplasia patients [22]. It is suggested that rs7166348 SNP may increase the activity or expression of IGF1 at the NSCLC progressive stage. However, the underlying mechanism should be elucidated in the future.

\section{Materials and Methods}

\subsection{Patient Specimens}

For the 2012-2015 period, we recruited 452 patients with NSCLC, including 362 adenocarcinoma lung cancer and 90 squamous cell carcinoma lung cancer patients, at Cheng-Ching General Hospital in Taichung, Taiwan. Medical information of the patients, including Tumor, Node, Metastasis (TNM) clinical staging, primary tumor size, lymph node involvement, and histologic grade, was obtained from their medical records. This study was approved by the Institutional Review Board of Cheng-Ching General Hospital (No. HP120009; 22 September 2012), and informed consent was obtained from all subjects.

\subsection{Genomic DNA Extraction and Insulin-Like Growth Factor 1 Receptor (IGF1R) Genotyping}

Venous blood from each subject was drawn into Vacutainer tubes containing EDTA and stored at $4{ }^{\circ} \mathrm{C}$. Genomic DNA was extracted by QIAamp DNA blood mini kits (Qiagen, Valencia, CA, USA) according to the manufacturer's instructions. Allelic discrimination of IGF1R rs7166348, rs2229765, and rs8038415 gene polymorphism was assessed with the ABI StepOne ${ }^{\text {TM }}$ Real-Time PCR System (Applied Biosystems, Foster City, CA, USA) and analyzed using SDS vers. 3.0 software (Applied Biosystems) with the TaqMan assay [21].

\subsection{Statistical Analysis}

The distributions of demographic characteristics and genotype frequencies between adenocarcinoma lung cancer and squamous cell carcinoma lung cancer, as well as clinicopathological features in different genotypes, were analyzed with a $\chi^{2}$-test. The odds ratio and $95 \%$ CIs of the association between the genotype frequencies and EGFR mutation risk and the clinical pathological characteristics were estimated using multiple logistic regression models after controlling for other covariates. A $p$-value of $<0.05$ was considered statistically significant. The data were analyzed with SAS statistical software (SAS Institute Inc., Cary, NC, USA). 


\section{Conclusions}

In conclusion, the mutation of EGFR was associated with adenocarcinoma, smoking status, and gender and the polymorphisms of the IGF1R rs2229765 gene were associated with the L858R mutation of EGFR in female lung adenocarcinoma patients who had never smoked. Furthermore, the polymorphism of IGFIR rs7166348 gene was associated with the clinical N stage of lung cancer. However, we are still lacking a mechanistic explanation for this phenomenon, which should be further investigated in the future.

Acknowledgments: This study was supported by a research grant from the Chung Shan Medical University (Taichung, Taiwan) and the Cheng-Ching General Hospital (Taichung, Taiwan) (CSMU-CCH-102-001). This study was also supported by a grant (CSH-2010-C-002, CSH-2011-C-004) from the Chung Shan Medical University Hospital, Taichung, Taiwan.

Author Contributions: Tu-Chen Liu, Ming-Che Liu, and Shun-Fa Yang conceived and designed the experiments; Ming-Che Liu and Whei-Ling Chiang performed the experiments; Thomas Chang-Yao Tsao and Shun-Fa Yang analyzed the data; Tu-Chen Liu contributed reagents/materials/analysis tools; Tu-Chen Liu, Ming-Ju Hsieh, Ming-Che Liu, and Shun-Fa Yang wrote the paper.

Conflicts of Interest: The authors declare no conflict of interest.

\section{Abbreviations}

$\begin{array}{ll}\text { IGF1 } & \text { insulin-like growth factor 1 } \\ \text { IGF1R } & \text { insulin-like growth factor 1 receptor } \\ \text { EGFR } & \text { epidermal growth factor receptor } \\ \text { NSCLC } & \text { non-small-cell lung carcinoma }\end{array}$

\section{References}

1. Travis, W.D. The 2015 who classification of lung tumors. Der Pathol. 2014, 35, 188. [CrossRef] [PubMed]

2. Sharma, S.V.; Bell, D.W.; Settleman, J.; Haber, D.A. Epidermal growth factor receptor mutations in lung cancer. Nat. Rev. Cancer 2007, 7, 169-181. [CrossRef] [PubMed]

3. Fumarola, C.; Bonelli, M.A.; Petronini, P.G.; Alfieri, R.R. Targeting PI3K/AKT/mTOR pathway in non small cell lung cancer. Biochem. Pharmacol. 2014, 90, 197-207. [CrossRef] [PubMed]

4. Da Cunha Santos, G.; Shepherd, F.A.; Tsao, M.S. EGFR mutations and lung cancer. Annu. Rev. Pathol. 2011, 6, 49-69. [CrossRef] [PubMed]

5. Siegelin, M.D.; Borczuk, A.C. Epidermal growth factor receptor mutations in lung adenocarcinoma. Lab. Investig. J. Tech. Methods Pathol. 2014, 94, 129-137. [CrossRef] [PubMed]

6. Lynch, T.J.; Bell, D.W.; Sordella, R.; Gurubhagavatula, S.; Okimoto, R.A.; Brannigan, B.W.; Harris, P.L.; Haserlat, S.M.; Supko, J.G.; Haluska, F.G.; et al. Activating mutations in the epidermal growth factor receptor underlying responsiveness of non-small-cell lung cancer to gefitinib. N. Engl. J. Med. 2004, 350, 2129-2139. [CrossRef] [PubMed]

7. Paez, J.G.; Janne, P.A.; Lee, J.C.; Tracy, S.; Greulich, H.; Gabriel, S.; Herman, P.; Kaye, F.J.; Lindeman, N.; Boggon, T.J.; et al. EGFR mutations in lung cancer: Correlation with clinical response to gefitinib therapy. Science 2004, 304, 1497-1500. [CrossRef] [PubMed]

8. Pao, W.; Miller, V.; Zakowski, M.; Doherty, J.; Politi, K.; Sarkaria, I.; Singh, B.; Heelan, R.; Rusch, V.; Fulton, L.; et al. EGF receptor gene mutations are common in lung cancers from "never smokers" and are associated with sensitivity of tumors to gefitinib and erlotinib. Proc. Natl. Acad. Sci. USA 2004, 101, 13306-13311. [CrossRef] [PubMed]

9. Yun, C.H.; Boggon, T.J.; Li, Y.; Woo, M.S.; Greulich, H.; Meyerson, M.; Eck, M.J. Structures of lung cancer-derived EGFR mutants and inhibitor complexes: Mechanism of activation and insights into differential inhibitor sensitivity. Cancer Cell 2007, 11, 217-227. [CrossRef] [PubMed]

10. Kumar, A.; Petri, E.T.; Halmos, B.; Boggon, T.J. Structure and clinical relevance of the epidermal growth factor receptor in human cancer. J. Clin. Oncol. 2008, 26, 1742-1751. [CrossRef] [PubMed]

11. Jung, H.J.; Suh, Y. Regulation of IGF-1 signaling by micrornas. Front. Genet. 2014, 5. [CrossRef] [PubMed]

12. Iams, W.T.; Lovly, C.M. Molecular pathways: Clinical applications and future direction of insulin-like growth factor-1 receptor pathway blockade. Clin. Cancer Res. 2015, 21, 4270-4277. [CrossRef] [PubMed] 
13. King, H.; Aleksic, T.; Haluska, P.; Macaulay, V.M. Can we unlock the potential of IGF-1R inhibition in cancer therapy? Cancer Treat. Rev. 2014, 40, 1096-1105. [CrossRef] [PubMed]

14. Crudden, C.; Girnita, A.; Girnita, L. Targeting the IGF-1R: The tale of the tortoise and the hare. Front. Endocrinol. 2015, 6. [CrossRef] [PubMed]

15. Zha, J.; Lackner, M.R. Targeting the insulin-like growth factor receptor-1R pathway for cancer therapy. Clin. Cancer Res. 2010, 16, 2512-2517. [CrossRef] [PubMed]

16. Zemva, J.; Schubert, M. Central insulin and insulin-like growth factor-1 signaling: Implications for diabetes associated dementia. Curr. Diabetes Rev. 2011, 7, 356-366. [CrossRef] [PubMed]

17. O'Neill, C.; Kiely, A.P.; Coakley, M.F.; Manning, S.; Long-Smith, C.M. Insulin and IGF-1 signalling: Longevity, protein homoeostasis and Alzheimer's disease. Biochem. Soc. Trans. 2012, 40, 721-727. [CrossRef] [PubMed]

18. Scagliotti, G.V.; Novello, S. The role of the insulin-like growth factor signaling pathway in non-small cell lung cancer and other solid tumors. Cancer Treat. Rev. 2012, 38, 292-302. [CrossRef] [PubMed]

19. Park, E.; Park, S.Y.; Kim, H.; Sun, P.L.; Jin, Y.; Cho, S.K.; Kim, K.; Lee, C.T.; Chung, J.H. Membranous insulin-like growth factor-1 receptor (IGF1R) expression is predictive of poor prognosis in patients with epidermal growth factor receptor (EGFR)-mutant lung adenocarcinoma. J. Pathol. Transl. Med. 2015, 49, 382-388. [CrossRef] [PubMed]

20. Reinmuth, N.; Kloos, S.; Warth, A.; Risch, A.; Muley, T.; Hoffmann, H.; Thomas, M.; Meister, M. Insulin-like growth factor 1 pathway mutations and protein expression in resected non-small cell lung cancer. Hum. Pathol. 2014, 45, 1162-1168. [CrossRef] [PubMed]

21. Stanilov, N.S.; Karakolev, I.A.; Deliysky, T.S.; Jovchev, J.P.; Stanilova, S.A. Association of insulin-like growth factor-i receptor polymorphism with colorectal cancer development. Mol. Biol. Rep. 2014, 41, 8099-8106. [CrossRef] [PubMed]

22. Bonafe, M.; Barbieri, M.; Marchegiani, F.; Olivieri, F.; Ragno, E.; Giampieri, C.; Mugianesi, E.; Centurelli, M.; Franceschi, C.; Paolisso, G. Polymorphic variants of insulin-like growth factor I (IGF-I) receptor and phosphoinositide 3-kinase genes affect IGF-I plasma levels and human longevity: Cues for an evolutionarily conserved mechanism of life span control. J. Clin. Endocrinol. Metab. 2003, 88, 3299-3304. [CrossRef] [PubMed]

23. Weng, C.J.; Hsieh, Y.H.; Tsai, C.M.; Chu, Y.H.; Ueng, K.C.; Liu, Y.F.; Yeh, Y.H.; Su, S.C.; Chen, Y.C.; Chen, M.K.; et al. Relationship of insulin-like growth factors system gene polymorphisms with the susceptibility and pathological development of hepatocellular carcinoma. Ann. Surg. Oncol. 2010, 17, 1808-1815. [CrossRef] [PubMed]

24. Shigematsu, H.; Lin, L.; Takahashi, T.; Nomura, M.; Suzuki, M.; Wistuba, I.I.; Fong, K.M.; Lee, H.; Toyooka, S.; Shimizu, N.; et al. Clinical and biological features associated with epidermal growth factor receptor gene mutations in lung cancers. J. Natl. Cancer Inst. 2005, 97, 339-346. [CrossRef] [PubMed]

25. Tokumo, M.; Toyooka, S.; Kiura, K.; Shigematsu, H.; Tomii, K.; Aoe, M.; Ichimura, K.; Tsuda, T.; Yano, M.; Tsukuda, K.; et al. The relationship between epidermal growth factor receptor mutations and clinicopathologic features in non-small cell lung cancers. Clin. Cancer Res. 2005, 11, 1167-1173. [CrossRef]

26. Won, Y.W.; Han, J.Y.; Lee, G.K.; Park, S.Y.; Lim, K.Y.; Yoon, K.A.; Yun, T.; Kim, H.T.; Lee, J.S. Comparison of clinical outcome of patients with non-small-cell lung cancer harbouring epidermal growth factor receptor exon 19 or exon 21 mutations. J. Clin. Pathol. 2011, 64, 947-952. [CrossRef] [PubMed]

(C) 2016 by the authors; licensee MDPI, Basel, Switzerland. This article is an open access article distributed under the terms and conditions of the Creative Commons Attribution (CC-BY) license (http://creativecommons.org/licenses/by/4.0/). 